\title{
Micropropagation of Kebericho: An Endandered Ethiopian Medicinal Plant
}

\author{
Begashaw Manahlie ${ }^{1,2}$, Tileye Feyissa ${ }^{2}$ \\ ${ }^{1}$ Department of Forestry, Wondo Genet College of Forestry and Natural Resource, Hawassa University, \\ Shashemene, Ethiopia \\ ${ }^{2}$ Institute of Biotechnology, Addis Ababa University, Addis Ababa, Ethiopia \\ Email: begashawm@gmail.com, feyissa@yahoo.com
}

Received 30 October 2014; revised 29 November 2014; accepted 9 December 2014

Copyright $(2014$ by authors and Scientific Research Publishing Inc.

This work is licensed under the Creative Commons Attribution International License (CC BY).

http://creativecommons.org/licenses/by/4.0/

(c) (i) Open Access

\begin{abstract}
Echinops kebericho, endemic to Ethiopia, is a critically endangered medicinal plant. It is among the most important medicinal plants of the country, valued primarily for its root parts. The commercial harvesting and sale of roots of $E$. kebericho have threatened local populations. This study aimed to develop micropropagation protocol for $E$. kebericho using shoot tip explants. The study started with seed germination test using seeds stored for different months. Shoot tips from in vitro germinated seedlings were cultured on shoot initiation MS media supplemented with $0,0.1,0.5$, 1.0, 1.5 and $2.0 \mathrm{mg} / \mathrm{l}$ BAP or KN alone. Explants were cultured on shoot proliferation media fortified with Kinetin, BAP, and TDZ each at 0.0, 0.5, 1.0, 2.5, 3.0 and $5.0 \mathrm{mg} / \mathrm{l}$ either alone or in combination with 0.0, 0.1, 0.25 and $0.5 \mathrm{mg} / \mathrm{l}$ NAA. For rooting, full, half and 1/3 strength MS media supplemented with IBA and NAA alone each at $0,0.05,0.1,0.5,1.0,1.5$ and $2.5 \mathrm{mg} / \mathrm{l}$ were used. Growth regulator free MS medium was used as control. Study results showed that $100 \%$ germination was recorded in fresh seeds and dropped as low as $65.18 \%$ and $22.3 \%$ for 3 and 5 months seeds respectively. $1.0 \mathrm{mg} / \mathrm{l} \mathrm{KN}$ and $0.5 \mathrm{mg} / \mathrm{l} \mathrm{KN}+0.1 \mathrm{mg} / \mathrm{l} \mathrm{NAA}$ showed maximum shoot proliferation on shoot induction media and shoot multiplication media respectively. Best rooting was obtained on $1 / 3$ MS containing $1.5 \mathrm{mg} / \mathrm{l}$ NAA with 8.23 roots and $4.82 \mathrm{~cm}$ root length and established under greenhouse with $83 \%$ survival.
\end{abstract}

Keywords

Echinops kebericho, Micropropagation, Shoot Tip, Plant Growth Regulator

\section{Introduction}

In many regions of Ethiopia where modern healthcare is not readily available or affordable, public continues to 
rely on traditional medicines. About $80 \%$ of human population and over $90 \%$ livestock in Ethiopia rely on traditional medicine where more than $95 \%$ of traditional medicinal preparations are of plant origin [1]. Echinops kebericho, known only in Ethiopia, is an erect massive root stock-bearing perennial herb or shrub that grows up to a height of $1.2 \mathrm{~m}$ with leafy stems [2]. It is among the most important medicinal plants of the country, valued primarily for its root parts [2]. Its varied medicinal applications are documented in the ancient medico-religious pharmacopoeia, and are well-recognized by modern-day traditional professionals [3]. Reports and ethnobotanical surveys also evidence long traditional use of the plant for preparation of medicines against migraine, mental illness, heart pain, lung TB, leprosy, kidney disease, malaria, billharzia, syphilis, hemorrhoid, amoebic dysentery and other ailments [4] [5]. Its antihelmintic, antitumor, antimutagenic, antibacterial and fungicidal properties have also been reported [6] [7]. The smoke from burning the root is inhaled to relieve headache, typhus fever and as a cure for "evil eye" (possession by evil spirits in Ethiopian folk religion). The root is burned to be used as a fumigant, mainly after childbirth, to ward off mosquitoes and as a snake repellant in the house [8]. The root is also chewed to alleviate stomach ache, as a taenicidal herb and a decoction from it is used to cure intestinal diseases in cattle [8]. In laboratory, the toxic properties of E. kebericho have been exploited in the control of insect pests of medical, veterinary and agricultural importance [9] [10]. The essential oil of E. kebericho also possesses strong antileishmanial activity higher than that of the most potent anti-leishmanial drugs with moderate cytotoxicity and weak haemolytic effects [7]. The bioactive extract of the species also has been shown to have antimicrobial effects equal to or better than penicillin, especially against Stereptococcus beta-haemolyticus, Escherchia coli and Klebsiela aerogenes [5]. Alkaloid extract of the roots of E. kebericho has been shown to have a very strong lethal activity against earthworm [11]. In the oil of E. kebericho, 43 compounds representing $92.85 \%$ of the total essential oil constituents were identified. The tubers are extremely rich in sesquiterpene amounting to about $10 \%$ of the dry weight of the tubers [12]. Therefore, this species is commercially viable to extract this compound [12], once it is propagated in large scale.

However, the loss of this valuable medicinal plant due to population pressure, loss of habitat, agricultural expansion and deforestation is widely reported. The commercial harvesting and sale of roots of E. kebericho has threatened local populations [13]. This may involve uprooting of the whole plant or removal of the root, which may seriously damage the root system. This poses a definite threat to the genetic stock. The large tuberous roots are sold in many open markets in Shewa, Gojjam, Wellega and southern regions of Ethiopia [14] [15]. Unlike most of the other species which occur naturally in nearby areas and are readily accessible to most local people, collecting of kebericho is reportedly carried out by specialized plant collectors who derive an income from its sale to local market vendors. In addition, E. kebericho propagates by seed which is incompetent due to lack of adequate seeds and seed viability loss after short period. Propagation through seeds is time consuming to accomplish large scale production for conservation and cultivation of the species. Despite these problems, the local people destruct the whole plant before seed set as they use the root part for medicinal purpose.

Problems related with its natural propagation and indiscriminate exploitation for medicinal use has put $E$. $k e-$ bericho in the list of critically endangered plant species of Ethiopia [16]. It is among few prioritized medicinal plants of Ethiopia that needs urgent conservation works through micropropagation. The value of developing micropropagation protocol for E. kebericho is very useful to preserve germplasm of this critically endangered species of high medicinal importance, to promote scientific activities (pharmacological studies and extraction of medicinally important compounds), commercial cultivation and sustainable usage of the species. No effort has been done for the mass propagation of this critically endangered plant species. Only one report is available on the in vitro and ex vitro seed based propagation of E. kebericho [17]. But the protocol discussed in this report lacks the large scale clonal production of this species from any type of vegetative explants. This study was therefore, conducted to develop micropropagation protocol for Echinops kebericho from shoot tip explants as a means to propagate and preserve germplasm of this critically endangered species of high medicinal importance as yet not been studied in Ethiopia.

\section{Materials and Methods}

\subsection{Plant Material}

Matured E. kebericho seeds were collected from the Medicinal Plant Garden of Ethiopian Health and Nutrition Research Institute (EHNRI), Addis Ababa University and the Ethiopian Biodiversity Institute (EBI) Botanical Garden, Wondo Genet, during October 2012. 


\subsection{Seed Sterilization and in Vitro Germination}

Freshly harvested seeds and those stored for 3 and 5 months were examined for germination and viability test. The seeds were washed thoroughly in tap water for 10 minutes, surface sterilized with $70 \%(\mathrm{v} / \mathrm{v})$ alcohol for 9 min and then in 5.25\% (w/v) sodium hypochlorite for $5 \mathrm{~min}$. Tween 20, 1 - 2 drops was used as a surfactant in the sterilants. Then the seeds were rinsed 4 - 5 times with sterilized $d_{d H_{2}} \mathrm{O}$ to remove traces of sterilants. The sterilized seeds were cultured on MS medium [18] with 8 replications and 14 seeds per culture vessel. Germinating seeds were counted and recorded at every 10 days interval until no further germination was recorded for the three seed lots. The first germinating seeds acted as the baseline for recording data. The germination test lasted for a month. The cultures were maintained at $25^{\circ} \mathrm{C} \pm 2^{\circ} \mathrm{C}$ and $16 \mathrm{~h}$ photoperiod under cool fluorescent light at light intensity of $22 \mu \mathrm{mol} \cdot \mathrm{m}^{-2} \cdot \mathrm{s}^{-1}$.

\subsection{Shoot Induction from Shoot Tip Explants}

Shoot tips of in vitro germinated seedlings were excised and cultured in Magenta jars $(10 \times 6 \mathrm{~mm})$ containing 50 $\mathrm{ml}$ medium supplemented with BAP $(0,0.1,0.5,1.0,1.5,3.0 \mathrm{mg} / \mathrm{l})$ and kinetin $(0,0.1,0.5,1.0,1.5,3.0 \mathrm{mg} / \mathrm{l})$. The medium was fortified with $30 \mathrm{~g} / \mathrm{l}$ sucrose $(\mathrm{w} / \mathrm{v})$ and the $\mathrm{pH}$ was adjusted to 5.8 before addition of $8 \mathrm{~g} / \mathrm{l}$ agar. Two explants per culture vessel and 15 replications per treatment were used. The cultures were maintained at $25^{\circ} \mathrm{C} \pm 2^{\circ} \mathrm{C}$ and $16 \mathrm{~h}$ photoperiod at a light intensity of $22 \mu \mathrm{mol} \cdot \mathrm{m}^{-2} \cdot \mathrm{s}^{-1}$ under white fluorescent light. After 4 weeks, growth responses were recorded as percentage of explants exhibiting new-growth, number of shoots per explant and shoot length.

\subsection{Shoot Multiplication}

Full strength MS medium supplemented with various concentrations of BAP (0.0, 0.5, 1.0, 2.5, 3.0, $5.0 \mathrm{mg} / \mathrm{l})$, Kinetin and TDZ either alone or in combination with $0.0,0.1,0.25,0.5 \mathrm{mg} / \mathrm{l}$ of NAA was used. A factorial design with 30 explants per treatment and 6 explants per vessel were used. Initiated shoots were excised and cultured on shoot multiplication medium and incubated under similar conditions as for culture initiation. Proliferation data were collected on percentage of explants showing proliferation, number of shoots per explant and shoot length every four weeks.

\subsection{In Vitro Rooting and Acclimatization}

Shoots from best proliferation medium were used to avoid the influence of different origin of media on shoots tested for rooting. Full, half and 1/3 strength MS media supplemented with IBA and NAA were used. Similar concentrations and levels $(0,0.05,0.1,0.5,1.0,1.5,2.5 \mathrm{mg} / \mathrm{l})$ were used for each type of auxin (IBA and NAA). The media were fortified with 30, 15 and $10 \mathrm{~g} / \mathrm{l}$ sucrose (w/v) for full, half and 1/3 strength MS medium respectively. In all cases, the media were solidified with $8 \mathrm{~g} / \mathrm{l}$ agar and adjusted to $5.8 \mathrm{pH}$ prior to autoclaving at $121^{\circ} \mathrm{C}$ for 15 min under 15 psi pressure. About 1.5 to $3 \mathrm{~cm}$ long micro shoots were excised from multiple shoots and then cultured in rooting media. Thirty explants per treatment and 6 shoots per culture vessel with 5 replicates were used. The number of shoots producing roots, number and length of roots were recorded. For acclimatization, well rooted shoots were removed from culture medium, washed thoroughly in sterilized $\mathrm{dH}_{2} \mathrm{O}$ and planted in plastic pots filled with sterilized compost, local soil and sand in a ratio of 1:3:1 respectively. The pots were then maintained in the culture room for two weeks followed by a transfer to greenhouse with $26^{\circ} \mathrm{C} \pm 3^{\circ} \mathrm{C}$ and relative humidity of $50 \%-60 \%$. Plant survival was recorded eight weeks after the plantlets were transplanted. Statistical analysis of the data were carried out using analysis of variance (ANOVA) and differences among treatment means were compared using Duncan's Multiple Range Test at 5\% probability level using SAS.

\section{Results}

\subsection{In Vitro Seed Germination}

Seed germination percentages significantly $(P=0.05)$ varied with the length of storage time (Table 1$)$. Germination was slow and did not begin within the initial 10 days for five-month-old seeds. In contrast, 3-month stored seeds began germinating within the first 10 days though percentage seed germination was low (39.29\%). Over the 30 days study period, the highest and more uniform (100\%) cumulative germination was recorded in 
Table 1. In vitro germination of E. kebericho seeds within thirty days of incubation period.

\begin{tabular}{ccccccc}
\hline \multirow{2}{*}{ Storage period } & \multicolumn{3}{c}{ Germination (\%) } & \multicolumn{3}{c}{ Mean no. of germinated seeds } \\
\cline { 2 - 6 } & Day 10 & Day 20 & Day 30 & Day 10 & Day 20 & Day 30 \\
\hline Fresh seeds & 68.75 & 95.54 & 100 & $9.63 \pm 0.50^{\mathrm{a}}$ & $13.38 \pm 0.57^{\mathrm{a}}$ & $14.0 \pm 0.00^{\mathrm{a}}$ \\
Three months & 39.29 & 59.82 & 65.18 & $5.50 \pm 0.26^{\mathrm{b}}$ & $8.38 \pm 0.60^{\mathrm{b}}$ & $9.13 \pm 0.55^{\mathrm{b}}$ \\
Five months & 0.0 & 13.39 & 22.32 & $0.0 \pm 0.00^{\mathrm{c}}$ & $1.88 \pm 0.61^{\mathrm{c}}$ & $3.13 \pm 0.35^{\mathrm{c}}$ \\
\hline
\end{tabular}

Means with the same letter within the same column are not statistically different $(P<0.05)$. The values represent mean \pm S.E.

the fresh seeds (Figure 1). On the other hand, relatively lower germination (65.18\%) was observed in threemonth-old seeds while lowest and erratic (22.32\%) germination was recorded in 5 months stored seeds.

\subsection{Shoot Induction from Shoot Tip Explants}

Shoot tips cultured on the control and on MS medium supplemented with BAP and KN alone, showed a significant variation $(P=0.05)$ in terms of percentage of shoots induced and number of shoots per explant (Table 2). All shoot tips produced proliferated shoots on MS medium supplemented with $0.5,1.0$ and $2.0 \mathrm{mg} / \mathrm{l} \mathrm{KN}$ while this result was observed only on MS medium containing $0.5 \mathrm{mg} / \mathrm{l} \mathrm{BAP.} \mathrm{On} \mathrm{the} \mathrm{other} \mathrm{hand,} \mathrm{the} \mathrm{lowest} \mathrm{shoot} \mathrm{indu}$ ction percentage was observed on the control with only 5 shoots exhibited new growth. Among MS media containing different concentrations of cytokinins, minimum shoot induction percentage (66.7\%) was recorded on MS medium supplemented with $1.0 \mathrm{mg} / \mathrm{l} \mathrm{BAP}$. In the present study, MS media supplemented with various concentrations of BAP were less effective than Kinetin containing MS media (Table 3, Figure 2). Medium supplemented with $1.0 \mathrm{mg} / \mathrm{l} \mathrm{KN}$ was found to be most conducive for culture induction from shoot tip explants of in vitro germinated seedlings. The highest number $(12.10 \pm 0.78)$ of shoots per explant was observed at this treatment. However, effect of cytokinins on shoot length did not vary much $(0.71-1.13 \mathrm{~cm})$ and remained more or less similar to that observed on basal medium $(0.78 \mathrm{~cm})$. Meanwhile, the shoots $(1.2 \mathrm{~cm})$ obtained on $2.0 \mathrm{mg} / \mathrm{l}$ BAP supplemented MS medium were significantly different.

\subsection{Shoot Multiplication}

There was a significant difference $(P<0.05)$ among the different treatment effects both in terms of shoot number per explant and shoot length. A maximum of $11.07 \pm 0.47$ shoots per explant was induced on MS medium supplemented with $0.5 \mathrm{mg} / \mathrm{l} \mathrm{KN}+0.1 \mathrm{mg} / \mathrm{l} \mathrm{NAA}$ (Table 4) whereas in the presence of $0.5 \mathrm{mg} / \mathrm{l} \mathrm{KN}$ alone, 10.73 \pm 0.56 shoots per explant were produced after 30 days of culture (Table 3). On the other hand, $10.33 \pm 0.46$ shoots per explant were induced in the presence of $1.0 \mathrm{mg} / \mathrm{l} \mathrm{TDZ}$ alone (Table 5). Shoots cultured on lower concentrations of KN and TDZ along with optimum concentration of NAA (0.1 - $0.25 \mathrm{mg} / \mathrm{l})$ showed better multiplication, beyond which the multiplication rate declined (Table 3 and Table 5). There was a general decline in shoot number and shoot elongation when any of the three cytokinins added alone or in combination with NAA at higher concentrations. At higher concentrations $(1.0-5.0 \mathrm{mg} / \mathrm{l})$ of BAP and $(0.25-0.5 \mathrm{mg} / \mathrm{l}) \mathrm{NAA}$, a mass of callus like material formed at the base of explants, resulting in reduced average shoot number (Figure 3). Type of cytokinins and their concentration had also a definite effect on shoot length. Among the three cytokinins used, $0.5 \mathrm{mg} / \mathrm{l} \mathrm{KN}$ in combination with $0.25 \mathrm{mg} / \mathrm{l}$ NAA showed most optimal $(1.68 \pm 0.13 \mathrm{~cm})$ effect on shoot elongation. The elongation obtained for KN either alone or in combination with NAA ranged from a minimal of $0.25 \pm$ $0.03 \mathrm{~cm}$ to a maximum of $1.68 \pm 0.13 \mathrm{~cm}$. These values varied between $0.29 \pm 0.03$ and $1.12 \pm 0.06 \mathrm{~cm}$ for the same concentrations as well as the combinations of TDZ and NAA. In case of similar concentrations and combinations of BAP and NAA, the values ranged between $0.21 \pm 0.02$ and $1.39 \pm 0.16 \mathrm{~cm}$. Thus, $\mathrm{KN}$ alone or in combination with NAA showed the highest variance in terms of shoot length.

\subsection{Rooting and Acclimatization}

Rooting was observed about 12 days after the transfer to rooting media and NAA was significantly $(P<0.05)$ more effective in promoting root induction than IBA on all strengths of MS media. Root induction was slow in the presence of IBA, with calli or abnormal roots observed at the base of the shoots at higher concentrations (Figure 4). The best rooting response was obtained on 1/3 strength MS medium supplemented with $1.5 \mathrm{mg} / \mathrm{l}$ NAA, on which $100 \%$ of cultured shoots developed roots with $8.30 \pm 0.60$ roots per shoot, and a length of 4.83 
Table 2. Effect of storage time on in vitro germination of E. kebericho seeds.

\begin{tabular}{ccccccc}
\hline \multirow{2}{*}{ Storage period } & \multicolumn{3}{c}{ Germination (\%) } & \multicolumn{3}{c}{ Mean no. of germinated seeds } \\
\cline { 2 - 7 } & Day 10 & Day 20 & Day 30 & Day 10 & Day 20 & Day 30 \\
\hline Fresh seeds & 68.75 & 95.54 & 100 & $9.63 \pm 0.50^{\mathrm{b}}$ & $13.38 \pm 0.57^{\mathrm{a}}$ & $14.0 \pm 0.00^{\mathrm{a}}$ \\
Three months & 39.29 & 59.82 & 65.18 & $5.50 \pm 0.26^{\mathrm{c}}$ & $8.38 \pm 0.60^{\mathrm{b}}$ & $9.13 \pm 0.55^{\mathrm{b}}$ \\
Five months & 0.0 & 13.39 & 22.32 & $0.0 \pm 0.00^{\mathrm{e}}$ & $1.88 \pm 0.61^{\mathrm{d}}$ & $3.13 \pm 0.35^{\mathrm{d}}$ \\
\hline
\end{tabular}

Means with the same letter within the same column are not statistically different $(P>0.05)$. The values represent mean \pm S.E.

Table 3. Effect of KN and BAP on shoot induction of shoot tip of E. kebericho.

\begin{tabular}{ccccc}
\hline PGRs $(\mathrm{mg} / \mathrm{l})$ & & Shoot induction $(\%)$ & Shoot number/explants & Shoot length $(\mathrm{cm})$ \\
\hline BAP & KN & & & $0.78 \pm 0.11^{\mathrm{ab}}$ \\
\hline 0.0 & 0.0 & 16.7 & $2.17 \pm 0.22^{\mathrm{ef}}$ & $0.71 \pm 0.10^{\mathrm{ab}}$ \\
0.25 & - & 83.3 & $2.00 \pm 0.20^{\mathrm{ef}}$ & $1.13 \pm 0.28^{\mathrm{ab}}$ \\
0.5 & - & 100 & $6.77 \pm 0.60^{\mathrm{c}}$ & $0.93 \pm 0.14^{\mathrm{ab}}$ \\
1.0 & - & 66.7 & $1.27 \pm 0.08^{\mathrm{f}}$ & $1.03 \pm 0.16^{\mathrm{ab}}$ \\
1.5 & - & 93.3 & $4.97 \pm 0.48^{\mathrm{cd}}$ & $1.20 \pm 0.25^{\mathrm{a}}$ \\
2.0 & - & 90 & $4.13 \pm 0.45^{\mathrm{de}}$ & $0.81 \pm 0.14^{\mathrm{ab}}$ \\
- & 0.25 & 90 & $3.77 \pm 0.36^{\mathrm{def}}$ & $0.78 \pm 0.15^{\mathrm{ab}}$ \\
- & 0.5 & 100 & $8.73 \pm 0.72^{\mathrm{ab}}$ & $0.88 \pm 0.16^{\mathrm{ab}}$ \\
- & 1.0 & 100 & $12.10 \pm 0.78^{\mathrm{a}}$ & $0.75 \pm 0.11^{\mathrm{ab}}$ \\
- & 1.5 & 96.7 & $5.67 \pm 0.41^{\mathrm{bc}}$ & $0.66 \pm 0.11^{\mathrm{b}}$ \\
\hline
\end{tabular}

Means with the same letter within the same column are not statistically different $(P>0.05)$. The values represent mean \pm S.E. Thirty explants per treatment were used.
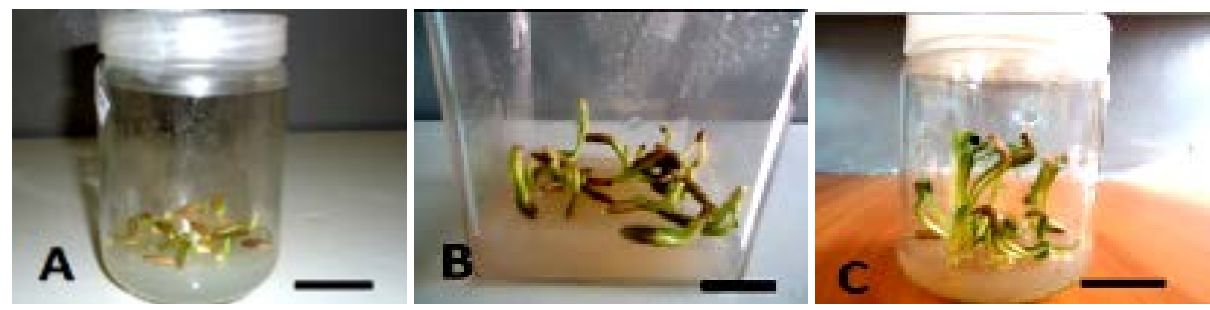

Figure 1. Fresh seeds germination rate within day 10 (A), day 20 (B), day 30 (C). Bars represent $2 \mathrm{~cm}$.
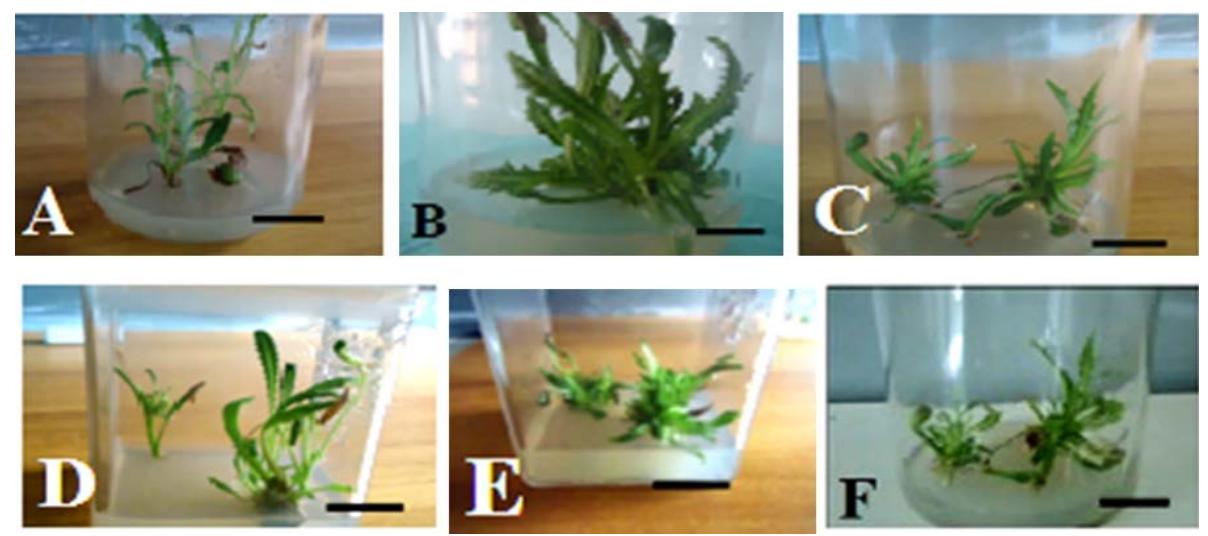

Figure 2. Effect of different concentrations of $\mathrm{KN}$ and BAP on shoot induction of shoot tip explants of E. kebericho: (A) control; $1.0 \mathrm{mg} / \mathrm{l} \mathrm{KN}$ (B); $2.0 \mathrm{mg} / \mathrm{l} \mathrm{KN} \mathrm{(C);} 0.25 \mathrm{mg} / \mathrm{l} \mathrm{KN}$ (D); $0.5 \mathrm{mg} / \mathrm{l} \mathrm{KN}$ (E) and $0.5 \mathrm{mg} / \mathrm{l} \mathrm{BAP} \mathrm{(F).} \mathrm{Bars} \mathrm{represent} 2 \mathrm{~cm}$. 

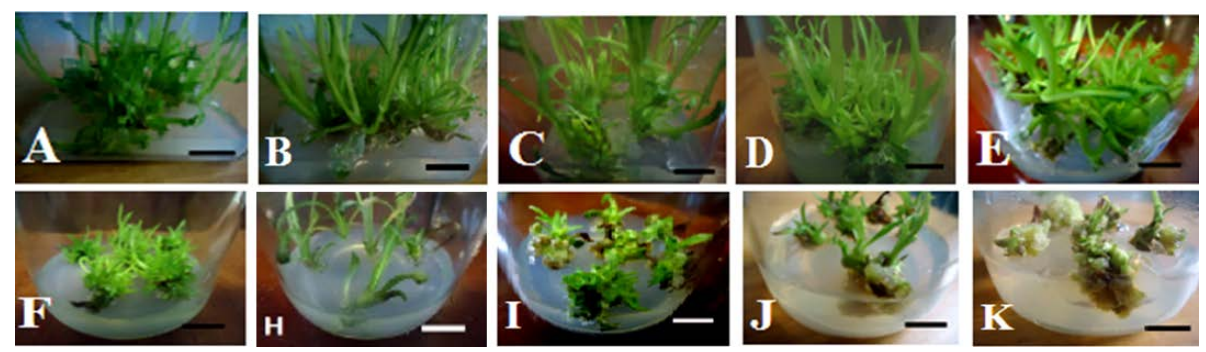

$\mathbf{K}-$

Figure 3. Multiple shoots of E. kebericho from shoot tip explants: (A) $0.5 \mathrm{mg} / \mathrm{l} \mathrm{KN}+0.1 \mathrm{mg} / \mathrm{l}$ NAA; (B) $0.5 \mathrm{mg} / \mathrm{l} \mathrm{KN}$; (C) $1.0 \mathrm{mg} / \mathrm{l} \mathrm{KN}$; (D) $1.0 \mathrm{mg} / \mathrm{l} \mathrm{TDZ;} \mathrm{(E)} 1.0 \mathrm{mg} / \mathrm{l} \mathrm{TDZ} \mathrm{+} 0.5 \mathrm{mg} / \mathrm{l}$ NAA; (F) $2.5 \mathrm{mg} / \mathrm{l} \mathrm{TDZ} \mathrm{+} 0.25 \mathrm{mg} / \mathrm{l} \mathrm{NAA}$; (H) Control; (I) $1.0 \mathrm{mg} / \mathrm{l} \mathrm{BAP} \mathrm{+} 0.5 \mathrm{mg} / \mathrm{l} \mathrm{NAA}$; (J) $\mathrm{KN}+\mathrm{NAA}$ each at $0.5 \mathrm{mg} / \mathrm{l} ;(\mathrm{K}) \mathrm{BAP}+\mathrm{NAA}$ each at $0.5 \mathrm{mg} / \mathrm{l}$. Bars represent $2 \mathrm{~cm}$.
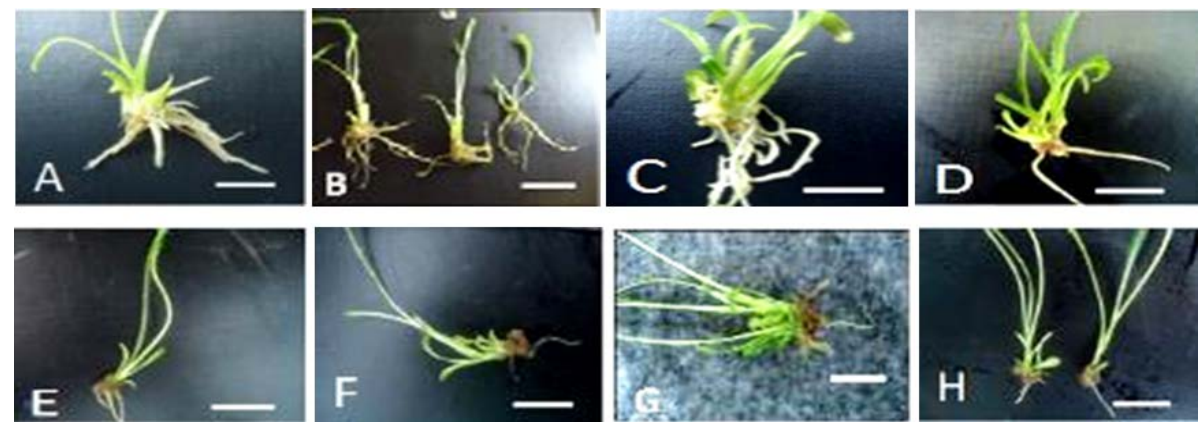

Figure 4. Rooted shoots of E. kebericho: (A) (B) 1/3 MS + 1.5 mg/l NAA; (C) 1/3 MS + 0.1 or $0.5 \mathrm{mg} / \mathrm{l} \mathrm{NAA}$; (D) 1/2 MS + $0.5 \mathrm{mg} / \mathrm{l} \mathrm{NAA}$; (E) 1/2 MS + $0.5 \mathrm{mg} / \mathrm{l} \mathrm{IBA;} \mathrm{(F)} 1 / 3 \mathrm{MS}+1.5$ mg/l IBA; (G) Full MS + 1.0 mg/l NAA; (H) Full MS + 2.5 mg/l NAA. Bars represent 2 cm

Table 4. Effect of different concentrations of KN alone or in combination with various concentrations of NAA on shoot organogenesis of shoot tip explants of E. kebericho.

\begin{tabular}{ccccc}
\hline & PGR (mg/l) & Proliferated explants $(\%)$ & No. of shoots/explants & Shoot length $(\mathrm{cm})$ \\
\hline KN & NAA & & & \\
\hline 0.0 & 0.0 & 66.7 & $2.27 \pm 0.24^{\text {ghi }}$ & $0.88 \pm 0.12^{\mathrm{c}}$ \\
0.5 & 0.0 & 100 & $10.73 \pm 0.56^{\mathrm{a}}$ & $1.28 \pm 0.09^{\mathrm{b}}$ \\
0.5 & 0.1 & 100 & $11.07 \pm 0.47^{\mathrm{a}}$ & $1.07 \pm 0.05^{\mathrm{c}}$ \\
0.5 & 0.25 & 100 & $7.03 \pm 0.48^{\mathrm{c}}$ & $1.68 \pm 0.13^{\mathrm{a}}$ \\
0.5 & 0.5 & 103.3 & $1.97 \pm 0.18^{\mathrm{hi}}$ & $0.40 \pm 0.04^{\mathrm{efg}}$ \\
1.0 & 0.0 & 93.3 & $8.37 \pm 0.50^{\mathrm{b}}$ & $1.47 \pm 0.12^{\mathrm{ab}}$ \\
1.0 & 0.1 & 100 & $6.07 \pm 0.55^{\mathrm{cd}}$ & $1.41 \pm 0.14^{\mathrm{b}}$ \\
1.0 & 0.25 & 100 & $5.37 \pm 5.57^{\mathrm{de}}$ & $0.60 \pm 0.05^{\mathrm{d}}$ \\
1.0 & 0.5 & 100 & $4.67 \pm 0.33^{\mathrm{def}}$ & $0.30 \pm 0.05^{\mathrm{g}}$ \\
2.5 & 0.0 & 100 & $4.83 \pm 0.54^{\mathrm{de}}$ & $0.30 \pm 0.03^{\mathrm{g}}$ \\
2.5 & 0.1 & 100 & $3.67 \pm 0.30^{\mathrm{efg}}$ & $0.25 \pm 0.03^{\mathrm{g}}$ \\
2.5 & 0.25 & 90 & $3.27 \pm 0.39^{\mathrm{ef}}$ & $0.59 \pm 0.04^{\mathrm{def}}$ \\
2.5 & 0.5 & 96.7 & $4.43 \pm 0.30^{\mathrm{fgh}}$ & $0.31 \pm 0.04^{\mathrm{g}}$ \\
3.0 & 0.0 & 90 & $4.00 \pm 0.37^{\mathrm{ef}}$ & $0.29 \pm 0.03^{\mathrm{g}}$ \\
3.0 & 0.1 & 33.3 & $1.60 \pm 0.19^{\mathrm{i}}$ & $0.28 \pm 0.02^{\mathrm{g}}$ \\
3.0 & 0.25 & 10 & $1.13 \pm 0.08^{\mathrm{i}}$ & $0.38 \pm 0.04^{\mathrm{efg}}$ \\
3.0 & 0.5 & 83.3 & $2.60 \pm 0.20^{\text {ghi }}$ & $0.28 \pm 0.03^{\mathrm{g}}$ \\
5.0 & 0.0 & 53.3 & $1.87 \pm 0.21^{\mathrm{hi}}$ & $0.61 \pm 0.04 \mathrm{~d}^{\mathrm{e}}$ \\
5.0 & 0.1 & 13.3 & $1.17 \pm 0.08^{\mathrm{i}}$ & $0.43 \pm 0.03^{\mathrm{defg}}$ \\
5.0 & 0.25 & 3.3 & $1.03 \pm 0.03^{\mathrm{i}}$ & $0.36 \pm 0.07^{\mathrm{fg}}$ \\
5.0 & 0.5 & & $0.28 \pm 0.03^{\mathrm{g}}$ \\
\hline
\end{tabular}

Means with the same letter within the same column are not statistically different $(P<0.05)$. The values represent mean \pm S.E. Thirty shoots per treatment were used. 
Table 5. Effect of different concentrations of BAP alone or in combination with various concentrations of NAA on shoot organogenesis of shoot tip explants of E. kebericho.

\begin{tabular}{ccccc}
\hline & PGR (mg/l) & Proliferated explants $(\%)$ & No. of shoots/explant & Shoot length $(\mathrm{cm})$ \\
\hline BAP & NAA & & & \\
\hline 0 & 0.0 & 66.7 & $2.27 \pm 0.24^{\text {bcd }}$ & $0.88 \pm 0.12^{\mathrm{b}}$ \\
0.5 & 0.0 & 56.7 & $2.30 \pm 0.29^{\text {bc }}$ & $0.47 \pm 0.04^{\mathrm{c}}$ \\
0.5 & 0.1 & 83.3 & $2.47 \pm 0.20^{\mathrm{b}}$ & $0.49 \pm 0.03^{\mathrm{c}}$ \\
0.5 & 0.25 & 50 & $2.33 \pm 0.33^{\text {bcd }}$ & $0.48 \pm 0.04^{\mathrm{c}}$ \\
0.5 & 0.5 & 30 & $1.37 \pm 0.11^{\text {cdef }}$ & $0.33 \pm 0.04^{\text {cd }}$ \\
1.0 & 0.0 & 20 & $1.23 \pm 0.09^{\text {cdef }}$ & $0.27 \pm 0.03^{\text {cd }}$ \\
1.0 & 0.1 & 76.7 & $2.13 \pm 0.16^{\text {bcdef }}$ & $0.21 \pm 0.02^{\text {d }}$ \\
1.0 & 0.25 & 10 & $1.17 \pm 0.10^{\text {def }}$ & $0.23 \pm 0.02^{\text {d }}$ \\
1.0 & 0.5 & 16.7 & $1.20 \pm 0.09^{\text {cdef }}$ & $0.31 \pm 0.04^{\text {cd }}$ \\
2.5 & 0.0 & 6.7 & $1.07 \pm 0.05^{\mathrm{f}}$ & $0.23 \pm 0.02^{\mathrm{d}}$ \\
2.5 & 0.1 & 16.7 & $1.20 \pm 0.09^{\text {cdef }}$ & $0.23 \pm 0.02^{\mathrm{d}}$ \\
2.5 & 0.25 & 10 & $1.13 \pm 0.08^{\text {ef }}$ & $0.28 \pm 0.02^{\text {cd }}$ \\
2.5 & 0.5 & 100 & $5.73 \pm 0.47^{\mathrm{a}}$ & $1.39 \pm 0.16^{\mathrm{a}}$ \\
3.0 & 0.0 & 76.7 & $2.23 \pm 0.17^{\text {bcde }}$ & $0.38 \pm 0.03^{\text {cd }}$ \\
3.0 & 0.1 & 66.7 & $1.93 \pm 0.15^{\text {bcdef }}$ & $0.32 \pm 0.03^{\text {cd }}$ \\
3.0 & 0.25 & 6.7 & $1.40 \pm 0.05^{\text {bcdef }}$ & $0.23 \pm 0.03^{\text {d }}$ \\
3.0 & 0.5 & 23.3 & $1.27 \pm 0.10^{\text {cdef }}$ & $0.28 \pm 0.03^{\text {cd }}$ \\
5.0 & 0.0 & 30 & $1.37 \pm 0.11^{\text {cdef }}$ & $0.39 \pm 0.09^{\text {cd }}$ \\
5.0 & 0.1 & 36.7 & $1.43 \pm 0.11^{\text {bcdef }}$ & $0.29 \pm 0.03^{\text {cd }}$ \\
5.0 & 0.25 & 3.3 & $1.03 \pm 0.03^{\text {ef }}$ & $0.36 \pm 0.09^{\text {d }}$ \\
5.0 & 0.5 & 3.3 & $1.03 \pm 0.43^{\text {bcdef }}$ & $0.29 \pm 0.03^{\text {cd }}$ \\
\hline
\end{tabular}

Means with the same letter within the same column are not statistically different $(P<0.05)$. The values represent mean \pm S.E. Thirty shoots per treatment were used.

$\pm 0.32 \mathrm{~cm}$ after 4 weeks culture. Rooting efficiency increased by increasing the concentration of NAA from 0.1 to $1.5 \mathrm{mg} / \mathrm{l}$ on $1 / 3$ strength MS medium (Table 6). Half-strength MS medium fortified with $0.05-1.0 \mathrm{mg} / \mathrm{l} \mathrm{IBA}$ also induced rooting but those roots were very thin and weak, making them fragile and prone to damage during transfer to ex vitro and easy to wither and die (Figure 4). On the other hand, MS medium fortified with 0.05, 0.5 or $1.0 \mathrm{mg} / \mathrm{l}$ IBA produced a few stunted roots on $1 / 3$ strength medium.

However, rooting was not observed on 1/3 strength MS medium containing 0.5 or $2.5 \mathrm{mg} / \mathrm{l} \mathrm{IBA}$ (Table 7). Similar results were noticed on half strength MS containing $1.5 \mathrm{mg} / \mathrm{l}$ or $2.5 \mathrm{mg} / \mathrm{l} \mathrm{NAA}$. On half strength plant growth regulator free medium, only $6.7 \%$ of shoots produced a single root with $3.25 \pm 0.25 \mathrm{~cm}$ root length. The rooted plants were successfully established under green house conditions with $83 \%$ survival rate (Figure 5).

\section{Discussion}

\subsection{In Vitro Seed Germination}

E. kebericho seeds had very low in vitro germination percentages after 5 months of storage. Seed germination declined with increased storage time. Seed viability in E. kebericho was reported to decrease fast when stored at room temperature $\left(25^{\circ} \mathrm{C}\right)$, but even storing at $4^{\circ} \mathrm{C}$ did not help much as the viability of seed stored at $4^{\circ} \mathrm{C}$ was about $70 \%$ after 10 months [17]. Generally, seeds of E. kebericho could not uniformly germinate after 3 months storage time. Hence, seeds of this species are characterized by short viability period when stored at room temperature, thus losing their capacity for germinating quickly.

\subsection{Shoot Induction from Shoot Tip Explants}

In culture initiation experiment, shoot tips cultured on control and those inoculated on MS medium supplemented with 0.25 - $2.0 \mathrm{mg} / \mathrm{l} \mathrm{BAP}$ and $\mathrm{KN}$ separately, showed a significant variation $(P>0.05)$. The results thus 
Table 6. Effect of different concentrations of TDZ alone or in combination with various concentrations of NAA on shoot organogenesis of shoot tip explants of E. kebericho.

\begin{tabular}{ccccc}
\hline \multicolumn{2}{c}{ PGR (mg/l) } & Proliferated explants $(\%)$ & No. of shoots/explants & Shoot length $(\mathrm{cm})$ \\
\hline TDZ & NAA & & & $0.88 \pm 0.12^{\mathrm{b}}$ \\
\hline 0.0 & 0.0 & 66.7 & $2.27 \pm 0.24^{\mathrm{g}}$ & $0.29 \pm 0.03^{\text {def }}$ \\
0.5 & 0.0 & 100 & $4.13 \pm 0.03^{\mathrm{f}}$ & $0.36 \pm 0.06^{\text {cdef }}$ \\
0.5 & 0.1 & 86.7 & $6.70 \pm 0.43^{\text {cde }}$ & $0.40 \pm 0.05^{\text {cdef }}$ \\
0.5 & 0.25 & 100 & $4.94 \pm 0.50^{\text {ef }}$ & $0.50 \pm 0.04^{\mathrm{a}}$ \\
0.5 & 0.5 & 100 & $8.20 \pm 0.45^{\mathrm{bc}}$ & $0.86 \pm 0.09^{\mathrm{b}}$ \\
1.0 & 0.0 & 100 & $10.33 \pm 0.46^{\mathrm{a}}$ & $1.04 \pm 0.06^{\text {ab }}$ \\
1.0 & 0.1 & 100 & $8.97 \pm 0.46^{\mathrm{ab}}$ & $1.12 \pm 0.06^{\mathrm{a}}$ \\
1.0 & 0.25 & 90 & $7.97 \pm 0.51^{\mathrm{bc}}$ & $0.84 \pm 0.06^{\mathrm{b}}$ \\
1.0 & 0.5 & 93.3 & $5.77 \pm 0.54^{\mathrm{def}}$ & $0.42 \pm 0.05^{\text {cdef }}$ \\
2.5 & 0.0 & 86.7 & $4.17 \pm 0.60^{\mathrm{f}}$ & $0.61 \pm 0.04^{\mathrm{c}}$ \\
2.5 & 0.1 & 76.7 & $5.43 \pm 0.40^{\mathrm{ef}}$ & $0.54 \pm 0.05^{\text {cde }}$ \\
2.5 & 0.25 & 70 & $5.00 \pm 0.47^{\mathrm{ef}}$ & $0.51 \pm 0.05^{\text {cdef }}$ \\
2.5 & 0.5 & 100 & $4.07 \pm 0.64^{\mathrm{f}}$ & $0.31 \pm 0.05^{\mathrm{ef}}$ \\
3.0 & 0.0 & 96.7 & $7.30 \pm 0.48^{\mathrm{bcd}}$ & $0.57 \pm 0.02^{\text {cd }}$ \\
3.0 & 0.1 & 3.3 & $7.63 \pm 0.39^{\mathrm{bc}}$ & $0.33 \pm 0.06^{\text {ef }}$ \\
3.0 & 0.25 & 3.3 & $1.03 \pm 0.55^{\mathrm{g}}$ & $0.32 \pm 0.02^{\text {ef }}$ \\
3.0 & 0.5 & 3.3 & $1.03 \pm 0.03^{\mathrm{g}}$ & $0.33 \pm 0.03^{\text {ef }}$ \\
5.0 & 0.0 & 33.3 & $1.03 \pm 0.03^{\mathrm{g}}$ & $0.32 \pm 0.03^{\mathrm{ef}}$ \\
5.0 & 0.1 & 10 & $1.53 \pm 0.03^{\mathrm{g}}$ & $0.29 \pm 0.04^{\mathrm{f}}$ \\
5.0 & 0.25 & 3.3 & $1.13 \pm 0.16^{\mathrm{g}}$ & $0.29 \pm 0.03^{\mathrm{f}}$ \\
\hline
\end{tabular}

Means with the same letter within the same column are not statistically different $(P<0.05)$. The values represent mean \pm S.E. Thirty shoots per treatment were used.

Table 7. Effect of different concentrations of NAA and IBA and MS basal media strength on in vitro rooting of E. kebericho shoots after 4 weeks of culturing.

\begin{tabular}{|c|c|c|c|c|c|c|}
\hline \multirow{3}{*}{ PGR (mg/l) } & \multicolumn{6}{|c|}{ MS medium strength } \\
\hline & \multicolumn{2}{|c|}{ Full MS } & \multicolumn{2}{|c|}{ Half MS } & \multicolumn{2}{|c|}{ 1/3 MS } \\
\hline & Root no/shoot & Root length & Root no/shoot & Root length & Root no/shoot & Root length \\
\hline \multicolumn{7}{|l|}{ IBA } \\
\hline 0.0 & $0.00 \pm 0.00^{\mathrm{e}}$ & $0.00 \pm 0.00^{\mathrm{e}}$ & $1.00 \pm 0.00^{\mathrm{b}}$ & $3.25 \pm 0.25^{\mathrm{d}}$ & $0.00 \pm 00^{\mathrm{e}}$ & $0.00 \pm 0.00^{g}$ \\
\hline 0.05 & $1.55 \pm 0.22^{\mathrm{bc}}$ & $3.55 \pm 0.96^{\mathrm{abc}}$ & $1.50 \pm 0.24^{\mathrm{b}}$ & $5.25 \pm 0.56^{\mathrm{a}}$ & $1.33 \pm 0.33^{\mathrm{de}}$ & $2.00 \pm 0.58^{\text {def }}$ \\
\hline 0.1 & $1.27 \pm 0.12^{\mathrm{cd}}$ & $4.80 \pm 0.80^{\mathrm{a}}$ & $1.33 \pm 0.33^{\mathrm{b}}$ & $4.33 \pm 0.73^{\mathrm{b}}$ & $1.33 \pm 0.33^{\mathrm{de}}$ & $2.17 \pm 0.44^{\mathrm{def}}$ \\
\hline 0.5 & $1.45 \pm 0.23^{\mathrm{bcd}}$ & $4.87 \pm 0.46^{\mathrm{a}}$ & $1.74 \pm 0.23^{\mathrm{b}}$ & $4.35 \pm 0.31^{\mathrm{b}}$ & $0.00 \pm 0.00^{\mathrm{e}}$ & $0.00 \pm 0.00^{\mathrm{g}}$ \\
\hline 1.0 & $1.00 \pm 0.00^{\mathrm{d}}$ & $2.13 \pm 0.97^{\mathrm{cd}}$ & $1.77 \pm 0.24^{\mathrm{b}}$ & $4.13 \pm 0.29^{\mathrm{bc}}$ & $1.33 \pm 0.33^{\mathrm{de}}$ & $2.67 \pm 0.33^{\mathrm{d}}$ \\
\hline 1.5 & $1.53 \pm 0.17^{\mathrm{bcd}}$ & $2.60 \pm 0.34^{\mathrm{bcd}}$ & $1.83 \pm 0.27^{\mathrm{b}}$ & $3.52 \pm 0.36^{\mathrm{d}}$ & $4.39 \pm 0.36^{c}$ & $5.38 \pm 0.28^{c}$ \\
\hline 2.5 & $1.33 \pm 0.33^{\text {bcd }}$ & $3.33 \pm 0.88^{\mathrm{abc}}$ & $1.00 \pm 0.00^{\mathrm{b}}$ & $3.50 \pm 0.50^{\mathrm{d}}$ & $0.00 \pm 0.00^{\mathrm{e}}$ & $0.00 \pm 0.00^{\mathrm{g}}$ \\
\hline \multicolumn{7}{|l|}{ NAA } \\
\hline 0.05 & $1.25 \pm 0.25^{\mathrm{cd}}$ & $3.88 \pm 0.43^{\mathrm{abc}}$ & $1.13 \pm 0.13^{b}$ & $3.31 \pm 0.44^{\mathrm{d}}$ & $1.35 \pm 0.18^{\mathrm{de}}$ & $2.43 \pm 0.27^{\text {de }}$ \\
\hline 0.1 & $1.17 \pm 0.17^{\mathrm{cd}}$ & $3.75 \pm 0.79^{\mathrm{abc}}$ & $1.47 \pm 0.47^{\mathrm{b}}$ & $3.75 \pm 0.31^{\text {cd }}$ & $6.36 \pm 0.63^{b}$ & $6.32 \pm 0.44^{\mathrm{b}}$ \\
\hline 0.5 & $1.14 \pm 0.14^{\text {cd }}$ & $4.00 \pm 0.65^{\mathrm{ab}}$ & $3.85 \pm 0.56^{\mathrm{a}}$ & $4.62 \pm 0.34^{\mathrm{b}}$ & $6.91 \pm 0.59^{\mathrm{b}}$ & $7.17 \pm 0.45^{\mathrm{a}}$ \\
\hline 1.0 & $2.44 \pm 0.34^{\mathrm{a}}$ & $1.47 \pm 0.12^{\mathrm{de}}$ & $1.43 \pm 0.18^{\mathrm{b}}$ & $1.00 \pm 0.11^{\mathrm{e}}$ & $1.93 \pm 0.36^{\mathrm{d}}$ & $1.45 \pm 0.37^{f}$ \\
\hline 1.5 & $2.30 \pm 0.28^{\mathrm{a}}$ & $2.07 \pm 0.15^{\mathrm{cd}}$ & $0.00 \pm 0.00^{c}$ & $0.00 \pm 0.00^{f}$ & $8.30 \pm 0.60^{\mathrm{a}}$ & $4.83 \pm 0.32^{\mathrm{c}}$ \\
\hline 2.5 & $1.82 \pm 0.27^{\mathrm{b}}$ & $1.18 \pm 0.12^{\mathrm{de}}$ & $0.00 \pm 0.00^{c}$ & $0.00 \pm 0.00^{\mathrm{f}}$ & $3.50 \pm 1.09^{c}$ & $1.69 \pm 0.41^{\mathrm{ef}}$ \\
\hline
\end{tabular}

Means with the same superscripts in the same column are not significantly different $(P>0.05)$. The values represent the mean \pm S.E. Thirty shoots per treatment were used. 


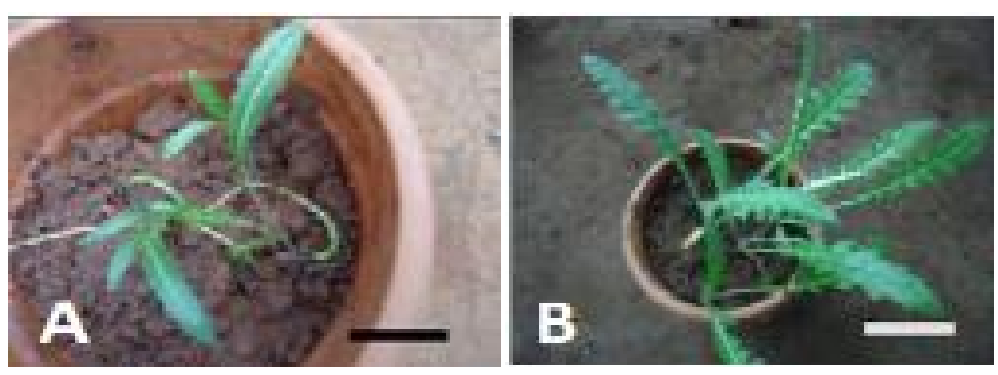

Figure 5. Acclimatization of in vitro rooted shoots of E. kebericho in glasshouse. (A) After 1 month; (B) After 3 months. Bars represent $2 \mathrm{~cm}$.

conclusively showed that cytokinins were essential for shoot induction and proliferation of shoot tip explants of E. kebericho. Kinetin at $1.0 \mathrm{mg} / \mathrm{l}$ concentration resulted in highest number of shoots (12.10 \pm 0.78$)$. In BAP, the newly formed shoots were abnormally looking, vitrified and stunted. In contrast, highest percentage of normal shoot induction was reported on MS medium containing $0.9 \mathrm{mg} / \mathrm{l}$ BAP from shoot tip explants in Mallotus repandus [19]. From several studies on micropropagation of medicinal plants, it has been found that $\mathrm{KN}$ is much more effective than BAP and this supports the results obtained from the present study [20] in Stevia rebaudiana; [21] in Sratia grosvenorii; [22] in Ionidium suffruticosum). The present result with KN was comparable with recent finding where $0.5 \mathrm{mg} / \mathrm{l} \mathrm{KN}$ resulted in maximum percentage of shoot initiation and shoot number in Psoralea corylifolia [23] from shoot tip explants.

\subsection{Shoot Multiplication}

In the present study, the highest number of shoots $(11.07 \pm 0.47)$ was recorded on MS medium containing 0.5 $\mathrm{mg} / \mathrm{KN}$ and $0.1 \mathrm{mg} / \mathrm{l} \mathrm{NAA}$ followed by $10.73 \pm 0.56$ shoots per explant on MS medium supplemented with 0.5 $\mathrm{mg} / \mathrm{l} \mathrm{KN}$. The maximum shoot induction probably is due to the synergistic activity of KN and NAA on shoot proliferation and growth of cells in E. kebericho. Addition of KN with NAA to MS medium was comparatively more effective for efficient shoot proliferation in shoot tip explants of E. kebericho, which is in agreement with earlier report of [24] in Bacopa monnieri. Similarly, [25] obtained highest number of shoots on MS medium supplemented with $1 \mathrm{mg} / \mathrm{l}$ kinetin and $0.5 \mathrm{mg} / \mathrm{l} \mathrm{NAA}$ with high frequency of shoot induction (95.5\%), maximum number of shoots (7.33) and even relatively longer shoots $(4.81 \mathrm{~cm})$ after four weeks of culture. Although maximum shoot proliferation (11.07 \pm 0.47 ) was observed on MS medium containing $0.5 \mathrm{mg} / \mathrm{l} \mathrm{KN}+0.1 \mathrm{mg} / \mathrm{l}$ NAA, this was not significantly different $(P>0.05)$ from the result $(10.33 \pm 0.46)$ obtained on MS medium containing $1.0 \mathrm{mg} / \mathrm{l} \mathrm{TDZ}$. Though, TDZ alone or in combination with NAA promoted higher frequency of shoot proliferation in shoot tip explants, shoots were short and failed to elongate even after prolonged culture. On the other hand, BAP alone or in combination with NAA gave significantly $(P>0.05)$ less number of shoots compared to the other, where a maximum of $5.73 \pm 0.47$ shoots per explant was obtained on MS medium containing $2.5 \mathrm{mg} / \mathrm{l} \mathrm{BAP}$ and $0.5 \mathrm{mg} / \mathrm{l} \mathrm{NAA}$. Conversely, greater number $(19.67 \pm 7.0)$ of multiple shoots were reported in Artemisia amygdalina from shoot tip explants in MS medium containing $0.2 \mathrm{mg} / \mathrm{l} \mathrm{BAP}+0.4 \mathrm{mg} / \mathrm{l} \mathrm{NAA}$ [26]. At higher levels though, there was no significant difference $(P<0.05)$ in frequency of multiple shoot proliferation of explants among all cytokinins. At higher concentrations of all the cytokinins alone or in combination with NAA, the average number of shoots per explant decreased significantly $(P>0.05)$ compared to the control, indicating an upper limit in concentration of cytokinins (KN, BAP and TDZ) and auxin (NAA) for E. kebericho.

Maximum (100\%) shoot proliferation frequency was recorded on a range of MS media supplemented with $\mathrm{KN}$ or TDZ either alone or in combination with NAA. On MS medium treated with BAP alone or in combination with NAA, Maximum (100\%) shoot proliferation result was observed only at $2.5 \mathrm{mg} / \mathrm{l} \mathrm{BAP}+0.5 \mathrm{mg} / \mathrm{l}$ NAA. The increased multiple shoot proliferation in the shoot tips may be due to rapid division of cells in the excised shoot tips and production of several primordial out growth, which eventually develop into shoots. Shoot length was also highly influenced by concentration and type of the growth regulators. On MS media containing BAP alone or in combination with NAA, there was no much difference in mean shoot length and it varied between $0.21 \pm 0.02$ and $0.49 \pm 0.03 \mathrm{~cm}$, except at $2.5 \mathrm{mg} / \mathrm{l} \mathrm{BAP}+0.5 \mathrm{mg} / \mathrm{l} \mathrm{NAA}$ where it resulted in better $(1.39 \pm$ $0.16 \mathrm{~cm}$ ) shoot length. Most of observed mean shoot lengths were smaller when compared to others, except for 
the case of $2.5 \mathrm{mg} / \mathrm{l} \mathrm{BAP}+0.5 \mathrm{mg} / \mathrm{l} \mathrm{NAA}$. Inhibition of shoot elongation by BAP was also reported in earlier studies on regeneration of different species of the Asteraceae family, for example in Saussurea obvallata [27] and Eclipta alba [28]. Among shoot elongation, $0.5 \mathrm{mg} / \mathrm{l} \mathrm{KN}+0.25 \mathrm{mg} / \mathrm{l}$ NAA showed the best mean shoot length of $1.68 \pm 0.13 \mathrm{~cm}$.

\subsection{Rooting and Acclimatization}

Roots were not spontaneously induced during culture initiation and shoot multiplication. When microshoots were cultured on growth regulators free half strength MS medium, poor and few (1.0) numbers of roots were elicited with low (6.7\%) frequency and $3.25 \pm 0.25 \mathrm{~cm}$ elongation. NAA was found to be more conducive than IBA for root induction. The effectiveness of NAA in rooting has been reported for medicinal plants like Vitis thunbergii [29], Spilanthes acmella [30] and Artemisia scoparia [31]. In the present study, the highest number (8.30 \pm 0.60$)$ of roots per shoot was observed on 1/3 strength MS medium supplemented with $1.5 \mathrm{mg} / \mathrm{l}$ NAA. On this medium, $100 \%$ shoots developed roots. The present results showed that a reduction in MS salt concentration is the pre-dominant reason for the improved rooting of in vitro shoots. The promotional effect of reducing the salt concentration of MS on in vitro rooting of shoots has been reported in Stevia rebaudiana [32]. Roots formed on medium containing NAA were thick and long whereas those in IBA were thin, short and weak. NAA showed significant difference on all media strengths in terms of root number per shoot after 4 weeks of culture. In this study, rooting was recorded on all strength MS medium containing different concentrations of IBA, although root formation was accompanied with callusing at the base of shoots in all concentrations. Further application of IBA up to $2.5 \mathrm{mg} / \mathrm{l}$ decreased the percentage of root induction, root numbers, and root lengths significantly. This observation is in agreement with the report of Thomas [33] in Curculigo orchioides where a higher level of IBA produced a negative effect resulting in lower root number and root length. The reason for low performance of IBA treatments may be due to the higher stability of IBA which induces higher level of degradative metabolites in tissue, and thus, blocking the regeneration process [34]. Studies also showed that, transport velocity of IBA was slower than NAA, which favors callus formation [35]. In this study, 1/3 strength MS medium supplemented with $1.5 \mathrm{mg} / \mathrm{l}$ NAA proved to be most effective for inducing a strong and stout root system where roots were high in number $(8.30 \pm 0.60)$ with average length of $4.83 \pm 0.32 \mathrm{~cm}$. Acclimatization of in vitro rooted plantlets was successful, where $83 \%$ plants survived and established as healthy plant. This result was much better than previous report by Balcha [17] where only $25 \%$ of in vitro germinated seedlings survived after being transferred to the greenhouse.

\section{Conclusion}

This study was the first description of micropropagation in E. kebericho. The present established micropropagation protocol for Echinops kebericho has a considerable practical significance and the process has to be successfully exploited for large scale production of cloned plants for their rehabilitation in natural habitat, ex vitro cultivation and sustainable utilization of this valuable medicinal plant. Seeds of E. kebericho could not be uniformly germinated after 3 months storage time. The superiority of $0.5 \mathrm{mg} / \mathrm{l} \mathrm{KN}+0.1 \mathrm{mg} / \mathrm{l} \mathrm{NAA}$ for shoot multiplication and 1/3 strength MS fortified with $1.5 \mathrm{mg} / \mathrm{l}$ NAA for inducing a resilient root system was established in this experiment.

\section{Acknowledgements}

Hawassa University, Addis Ababa University and Wondo Genet Agricultural Research Center are gratefully acknowledged for financial support.

\section{References}

[1] Tesema, T., Mirutse, G., Negussu, A. and Teshome, H. (2003) Medicinal Plants Biodiversity. National Biodiversity Strategy and Action Plan (NBSAP) Project, IBCR, Addis Ababa.

[2] Getachew, B., Yinebeb, T., Taddesse, K., Ariaya, H. and Yalemtsehay, M. (2011) Ethnopharmacological Investigations of Essential Oils Isolated from Five Ethiopian Medicinal Plants against Eleven Pathogenic Bacterial Strains. Phytopharmacology, 1, 133-143.

[3] Hareya, F. (2003) Local Health Knowledge and Home-Based Medicinal Plant Use in Ethiopia. International Develop- 
ment Centre. Ph.D. Dissertation, Oxford University, Oxford.

[4] Dawit, A. and Ahadu, A. (1993) Medicinal Plants and Enigmatic Health Practices of Northern Ethiopia. Berhanena Selam Printing Press, Addis Ababa.

[5] Belachew, D. (1993) Ethiopian Traditional Herbal Drugs. Part II: Antimicrobial Activity of Medicinal Plants. Journal of Ethnopharmacology, 39, 129-139.

[6] Abegaz, B., Mutanyatta-Comar, J. and Nindi, M. (2007) Naturally Occurring Homoisoflavonoids: Phytochemistry, Biological Activities and Synthesis. Natural Product Communications, 2, 475-498.

[7] Tariku, Y., Hymete, A., Hailu, A. and Rohloff, J. (2011) In Vitro Evaluation of Antileishmanial Activity and Toxicity of Essential Oils of Artemisia absinthium and Echinops kebericho. Chemistry \& Biodiversity, 8, 614-623. http://dx.doi.org/10.1002/cbdv.201000331

[8] Hymete, A., Rohloff, J., Iversen, T.H. and Kjøsen, H. (2007) Volatile Constituents of the Roots of Echinops kebericho Mesfin. Flavour and Fragrance Journal, 22, 35-38. http://dx.doi.org/10.1002/ffj.1746

[9] Hymete, A. and Kidane, A. (1991) Screening for Anthelmintic Activity in Two Echinops spp. Ethiop. The Pharmaceutical Journal, 9, 67-71.

[10] Jemal, H., Kaba, U., Fayissa, R., Awol, J., Sultan, A. and Nazif, H. (2011) Antihelmentic Effects of the Essential Oil Extracts of Selected Medicinal Plants against Haemonchus contortus. International Journal of Agricultural Research, 6, 290-298. http://dx.doi.org/10.3923/ijar.2011.290.298

[11] Hymete, A. and Afifi, M.S. (1997) Investigation of the Fixed Oil Isolated from the Roots of Echinops kebericho Mesfin. Mansoura. Journal of Pharmacological Sciences, 13, 59-69.

[12] Abegaz, B. (1996) Progress in the Chemistry of Marketed Traditionally Used Plants of Ethiopia-Review Article. Bulletin of the Chemical Society of Ethiopia, 10, 57-71.

[13] Cunningham, A.B. (1993) African Medicinal Plants: Setting Priorities at the Interface between Conservation and Primary Health Care. UNESCO, Nairobi, People and Plants Working Paper 1.

[14] Mesfin, T. and Brook, M. (2010) A Review of Selected Plants Used in the Maintenance of Health and Wellness in Ethiopia. Ethiopian e-Journal for Research and Innovation Foresight, 2, 85-102.

[15] Reta, R. (2013) Assessment of Indigenous Knowledge of Medicinal Plant Practice and Mode of Service Delivery in Hawassa City, Southern Ethiopia. Journal of Medicinal Plants Research, 7, 517-535.

[16] Global Environment Facility (2012) Capacity Building for Access and Benefit Sharing and Conservation and Sustainable Use of Medicinal Plants. Ethiopia ABS CSUMP CEO Endorsement Document. www.theGEF.org

[17] Balcha, A., Legesse, N. and Jochen, K. (2009) In Vitro and ex Vitro Seed-Based Propagation Methods of Echinops kebericho Mesfin: A Threatened Medicinal Plant. Journal of Applied Horticulture, 10, 164-168.

[18] Murashige, T. and Skoog, F. (1962) A Revised Medium for Rapid Growth and Bioassays with Tobacco Tissue Cultures. Physiologia Plantarum, 15, 473-497. http://dx.doi.org/10.1111/j.1399-3054.1962.tb08052.x

[19] Kaewsuwan, S., Soonthornchareonnon, N. and Prathanturarug, S. (2005) In Vitro Propagation of Mallotus repandus (Willd.) Muell. Arg. Acta Horticulturae, 2, 95-101.

[20] Ali, A., Gull, I., Naz, S. and Afghan, S. (2010) Biochemical Investigation during Different Stages of in Vitro Propagation of Stevia rebaudiana. Pakistan Journal of Botany, 42, 2827-2837.

[21] Yan, H.B., Liang, C.X., Yang, L.T. and Li, Y.R. (2010) In Vitro and ex Vitro Rooting of Sratia grosvenorii, a Traditional Medicinal Plant. Acta Physiologiae Plantarum, 32, 115-120. http://dx.doi.org/10.1007/s11738-009-0386-0

[22] Arunkumar, B.S. and Jayaraj, M. (2011) Effect of Auxins and Cytokinins on in Vitro Propagation of Ionidium suffruticosum Giing-A Seasonal Multipotent Medicinal Herb. International Journal of Research in Ayurveda and Pharmacy, 2, 198-203.

[23] Pandey, P., Mehta, R. and Adhyay, R. (2013) In Vitro Propagation of an Endangered Medicinal Plant Psoralea corylifolia Linn. Asian Journal of Pharmaceutical and Clinical Research, 6, 115-118.

[24] Pandiyan, P. and Selvaraj, T. (2012) In Vitro Multiplication of Bacopa monnieri (L.) Pennell from Shoot Tip and Nodal Explants. Journal of Agricultural Technology, 8, 1099-1108.

[25] Gopal, G.V., Repalle, S., Talluri, V.R., Ronda, S.R. and Allu, P.R. (2013) In Vitro Propagation and GC-MS Studies of Ocimum basilicum Linn. var. pilosum (Willd.) Benth. British Biotechnology Journal, 4, 96-107. http://dx.doi.org/10.9734/BBJ/2014/6225

[26] Rasool, R., Ganai, B.A., Kamili, A.N., Akbar, S. and Masood, A. (2013) Synergistic Effect of Auxins and Cytokinins on Propagation of Artemisia amygdalina (Asteraceae), a Critically Endangered Plant of Kashmir. Pakistan Journal of Botany, 45, 629-634.

[27] Joshi, M. and Dhar, U. (2003) In Vitro Propagation of Saussurea obvallata (DC.) Edgew._-An Endangered Ethnore- 
ligious Medicinal Herb of Himalaya. Plant Cell Reports, 21, 933-939. http://dx.doi.org/10.1007/s00299-003-0601-1

[28] Baskaran, P. and Jayabalan, N. (2005) An Efficient Micropropagation System for Eclipa alba-A Valuable Medicinal Herb. In Vitro Cellular \& Developmental Biology-Plant, 41, 532-539. http://dx.doi.org/10.1079/IVP2005667

[29] Lu, M.C. (2005) Micropropagation of Vitis thunbergii Sieb. et Zucc., a Medicinal Herb, through High-Frequency Shoot Tip Culture. Scientia Horticulturae, 107, 64-69. http://dx.doi.org/10.1016/j.scienta.2005.05.014

[30] Sharma, S. and Shahzad, A. (2013) Efficient Micropropagation of Spilanthes acmella (L.) Murr: A Threatened Medicinal Herb. British Biotechnology Journal, 3, 1-11.

[31] Aslam, N., Zia, M. and Chaudhary, M.F. (2006) Callogenesis and Direct Organogenesis of Artemisia scoparia. Pakistan Journal of Biological Sciences, 9, 1783-1786. http://dx.doi.org/10.3923/pjbs.2006.1783.1786

[32] Patel, R.M. and Shah, R.R. (2009) Regeneration of Stevia Plant through Callus Culture. Indian Journal of Pharmaceutical Sciences, 71, 46-50. http://dx.doi.org/10.4103/0250-474X.51954

[33] Thomas, T.D. (2007) Pretreatment in Thidiazuron Improves the in Vitro Shoot Induction from Leaves in Curculigo orchioides Gaertn, an Endangered Medicinal Plant. Acta Physiologiae Plantarum, 29, 455-461. http://dx.doi.org/10.1007/s11738-007-0055-0

[34] Baker, C.M. and Wetzstein, H.Y. (2004) Influence of Auxin Type and Concentration on Peanut Somatic Embryogenesis. Plant Cell, Tissue and Organ Culture, 36, 361-368. http://dx.doi.org/10.1007/BF00046094

[35] Kaldewey, H. (1984) Transport and Other Modes of Movements of Hormones (Mainly Auxins). In: Scott, T.K., Ed., Hormonal Regulation of Development II, Encyclopedia of Plant Physiology, New Series, Vol. 10, 80-148. 
Scientific Research Publishing (SCIRP) is one of the largest Open Access journal publishers. It is currently publishing more than 200 open access, online, peer-reviewed journals covering a wide range of academic disciplines. SCIRP serves the worldwide academic communities and contributes to the progress and application of science with its publication.

Other selected journals from SCIRP are listed as below. Submit your manuscript to us via either submit@scirp.org or Online Submission Portal.
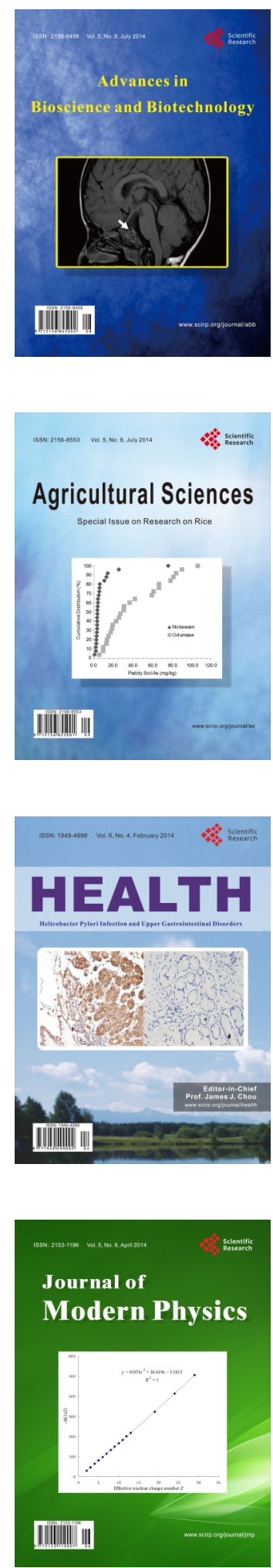
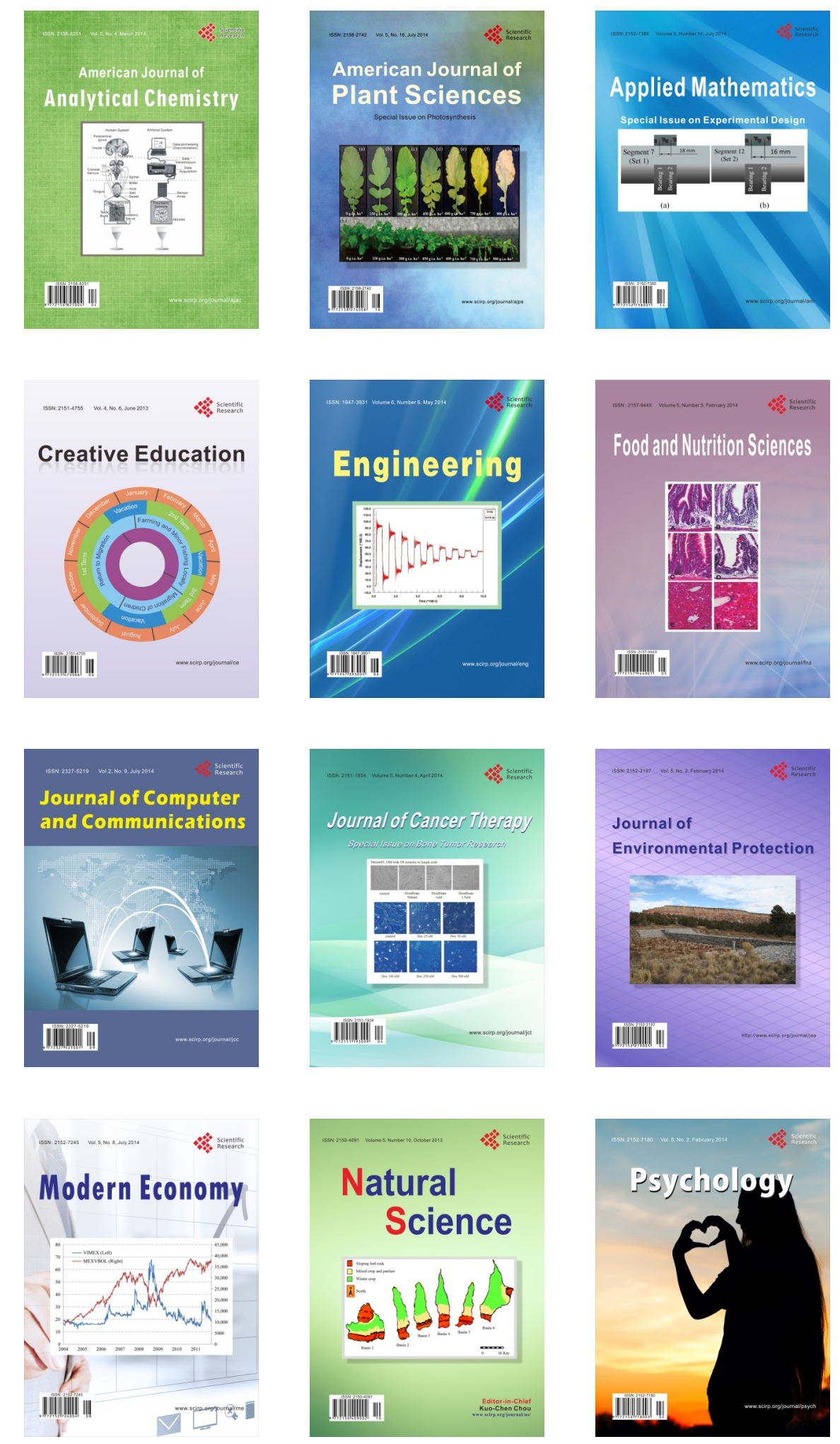